\title{
Sustainable cementitious materials: The effect of fly ash percentage as a part replacement of portland cement composite (PCC) and curing temperature on the early age strength of fly ash concrete
}

\author{
Gidion Turuallo ${ }^{1, *}$, Harun Mallisa ${ }^{1}$ \\ ${ }^{1}$ Civil Engineering Department, Tadulako University, Palu, Indonesia
}

\begin{abstract}
This research aims to determine the effect of fly ash percentage as a part replacement of Portland cement and curing temperatures to the early age strength of concrete. The percentages of fly ash used were 0,10 and $15 \%$ by cement weight. The cured temperatures were 25,30 dan $50^{\circ} \mathrm{C}$. The concrete specimens were cubes of $150 \times 150 \times 150 \mathrm{~mm}^{3}$. The cubes, which were cured at $25^{\circ} \mathrm{C}$, placed in water tank, while those cured at 30 and $50^{\circ} \mathrm{C}$ cured in oven until 7 days and then continued in water. The testing was conducted at ages 3, 7, 14 dan 28 days. The results showed that at early ages, the strength of concrete without fly ash cured at $25^{\circ} \mathrm{C}$ were higher than that of fly ash concrete. The higher level replacement of cement with fly ash, the lower strength of concrete obtained. The higher the curing temperature at earlier age resulted the higher the strength of concrete. The strength of concretes with $10 \%$ of fly ash cured at 25,30 and $50^{\circ} \mathrm{C}$ at age three days were $15.111,15.481$ and 16.296 MPa respectively. Conversely, the strength of concrete that of cured at higher temperatures at ages 28 days, were lower than that of concretes cured at lower temperature. The results of this research also showed that fly ash could improve the workability of concrete.
\end{abstract}

\section{Introduction}

Concrete is the most used construction material worldwide due to its availability of the raw materials over the world. For many arguments, the production of cement as a construction material is not sustainable, as it consumes large quantities of natural materials. It is about 1.5 tons of raw materials is needed in producing each tone of cement. Another reason is the cement, which is the main material in producing concrete, has a large contribution to the $\mathrm{CO}_{2}$ emission that leads to global warming and climate change. It is approximately one ton of $\mathrm{CO}_{2}$, is released to the atmosphere in producing each ton of cement [1-5].

The cement manufacturing is discovered to need large amounts of energy. Embodied energy is the total energy required to produce a new material. Those are needed to extract the raw material, process and manufacture material, and transportation for all stages of production. For this reason, it is needed to develop cementitious materials, which are waste by product of industry and consume a smaller amount of energy in producing them and can reduce the cement content to be used in concrete. Furthermore, the use such materials may give additional benefits and improve certain properties such as strength, workability and durability of concrete. The use of cementitious materials can have impact on the environment and contribution to reduce the need of landfill for disposal $[3,4,6]$. The use of fly ash as cementitious material in concrete can play an important role in sustainable development. It has been introduced for using as supplementary cementitious material in concrete in the beginning of last century, although it was started to be familiar used in concrete in the last 50 years [7].

\section{Using fly ash in concrete}

Fly ash is a by-product of burning pulverized of a coalfired electrical generation station. The mineral impurities in the coal (clay, feldspar, quartz and shale) are separated out of combustion chamber along with exhaust gases. It then cools and solidifies into spherical glassy particles called fly ash $[8,9]$. Generally, fly ash is used to replace original Portland cement in concrete up to $30 \%$ by mass of the total binder or cementitious material $[10,11]$. The use of fly ash as addition in concrete

* Corresponding author: turuallo@yahoo.co.uk 
mixture can give many economical, technical and environmental benefits.

\subsection{Pozzolanic reaction of fly ash}

Pozzolanic reactions refer to the chemical reaction between the calcium hydroxide $(\mathrm{CH})$ resulted from the cement hydration process and the silica dioxide inside of the fly ash. The hydration reaction as follows [12]:

Primary reaction:

$$
\begin{aligned}
& 2 \mathrm{C}_{3} \mathrm{~S}+6 \mathrm{H} \longrightarrow \mathrm{C}_{3} \mathrm{~S}_{2} \mathrm{H}_{3}+3 \mathrm{CH} \\
& \text { tricalcium silicate }+ \text { water } \longrightarrow \mathrm{C}-\mathrm{S}-\mathrm{H}+\text { calcium } \\
& \text { hydroxide }
\end{aligned}
$$

Secondary reaction:

$$
\begin{aligned}
2 \mathrm{C}_{2} \mathrm{~S}+4 \mathrm{H} \longrightarrow \mathrm{C}_{3} \mathrm{~S}_{2} \mathrm{H}_{3}+\mathrm{CH} \\
\text { dicalcium silicate }+ \text { water } \longrightarrow \mathrm{C}-\mathrm{S}-\mathrm{H}+\text { calcium } \\
\text { hydroxide }
\end{aligned}
$$

The hydration reaction of cement then followed by the pozzolanic reactions below:

$$
\mathrm{CH}+\mathrm{S}+\mathrm{H} \longrightarrow \mathrm{C}-\mathrm{S}-\mathrm{H}
$$

Fly ash reacts with lime $(\mathrm{CH})$, the by-product of the cement hydration and results $\mathrm{C}-\mathrm{S}-\mathrm{H}$ gels, which account for the main strength of concrete. The more C-S-H produced in hydration and pozzolanic reactions the stronger concrete obtained. In addition, the use of fly ash in concrete can reduce the rate of the heat hydration as the heat produced in cement hydration is used by fly ash in the secondary reaction as activation energy to start the pozzolanic reaction $[13,14]$. Therefore, the temperature rise resulted from cement hydration accelerates the secondary reaction of fly ash in concrete, thereby it can reduce possible thermal cracks.

\subsection{Effect of fly ash on the properties of fresh and hardened concrete}

The use of fly as in concrete can reduce the water needed in mixing depends on the quality of fly ash used, as the fly ash can improve workability of concrete. It also can reduce bleeding and avoid segregation [15] as the less water used in concrete making it more cohesive. The reaction of fly ash with $\mathrm{CH}$ to produce $\mathrm{CSH}$ will increase concrete density, thus lowering the permeability of concrete to water and aggressive chemicals such as chloride ion, salts and sulphate compounds. As the results it will increase the durability of concrete. Furthermore, increasing the CSH compound in concrete, will results improving in strength.

\section{Experimental Works}

\subsection{Materials}

A single batch of sand, coarse aggregate, PCC cement, and fly ash were used throughout the experimental work. The PCC cement was produced by PT Semen Tonasa, which was PPC Type I cement with the specific gravity of 3.1. The absorption, density, and sieve analysis of both coarse and fine aggregates were measured in the laboratory. The sand was fine sand taken from Palu River and the coarse aggregate was a crushed aggregate produced by stone crushed PT Beton Jaya, Palu with a nominal size ranging from 5 to $20 \mathrm{~mm}$. Both the sand and coarse aggregate were in air dry conditions; therefore, some water were added for absorption to allow both of them meet their saturated service dry (SSD) condition. The fly ash, which was used in this research, was taken from power generating (PLTU) Mpanau Palu with the chemical composition shown in Table 1 . The fly ash was categorized as fly ash Class $\mathrm{F}$ with the specific gravity of 2.377 .

Table 1. The chemical composition of fly ash taken from PLTU Mpanau Palu

\begin{tabular}{|c|c|}
\hline $\begin{array}{c}\text { Chemical } \\
\text { compounds }\end{array}$ & Percentage by weight \\
\hline $\mathrm{SiO}_{2}$ & 51.55 \\
\hline $\mathrm{Fe}_{2} \mathrm{O}_{3}$ & 25.54 \\
\hline $\mathrm{Al}_{2} \mathrm{O}_{3}$ & 17.26 \\
\hline $\mathrm{CaO}$ & 2.09 \\
\hline $\mathrm{K}_{2} \mathrm{O}$ & 1.25 \\
\hline $\mathrm{TiO}{ }_{2}$ & 0.95 \\
\hline $\mathrm{MnO}$ & 0.48 \\
\hline $\mathrm{Others}$ & 0.90 \\
\hline
\end{tabular}




\subsection{Mix proportions}

The mix proportions of concrete per $\mathrm{m} 3$ of concrete with and without fly ash are presented in Table 2 as follow:

Table 2 The chemical composition of fly ash taken from PLTU Mpanau Palu

\begin{tabular}{|c|c|c|c|}
\hline \multirow{2}{*}{ Materials } & \multicolumn{3}{|c|}{ Mix proportion per $\mathrm{m}^{3}$ concrete } \\
\cline { 2 - 4 } & $\begin{array}{c}\text { PCC } \\
\text { Concrete } \\
\% \mathrm{FA})\end{array}$ & $10 \% \mathrm{FA}$ & $15 \% \mathrm{FA}$ \\
\hline Cement (kg) & 394 & 354.6 & 334.9 \\
\hline Fly ash (kg) & - & 39.4 & 59.1 \\
\hline $\begin{array}{c}\text { Sand (kg) } \\
\text { Coarse } \\
\text { Aggregate } \\
\text { (kg) }\end{array}$ & 1041 & 1041 & 1041 \\
\hline $\begin{array}{c}\text { Water (kg) } \\
\text { Myyy }\end{array}$ & 211 & 211 & 211 \\
\hline
\end{tabular}

The water-cement ratios of those mixes above are 0.52. After mixing, the cube moulds were half filled with concrete then vibrated. The moulds then filled up to the top before they were vibrated again to have a sufficient level of compaction.

\subsection{Specimens}

The specimens are concrete cubes with the size of 150 $\mathrm{mm} \times 150 \mathrm{~mm} \times 150 \mathrm{~mm}$. Three cubes for each mix and testing date provided. The testing ages are 3, 7, 14 and 28-days. The specimens were cured at $25{ }^{0} \mathrm{C}$ (room temperature), 30 and $50{ }^{\circ} \mathrm{C}$ in ovens.

\section{Results and discussions}

The results of slump test for concrete with 0,10 and 15\% FA were 100, 120 and $135 \mathrm{~mm}$ respectively. Replace $15 \%$ cement by fly ash can improve the slump of concrete by $35 \%$ higher than slump of concrete without fly ash. It is meant that using fly ash in concrete can improve the workability of concrete. The workability of concrete improves as the percentage of fly ash in concrete increase.

Table 3 below presents the results of compression strengths testing of concrete PCC, 10FA and 15FA cured at 25,30 and $50^{\circ} \mathrm{C}$ at ages $3,7,14$ and 28 days. The symbols PCC, 10FA and 15 FA refer to the PCC, $10 \%$ FA and $15 \%$ FA concretes respectively.
Table 3 The results of compression strength testing

\begin{tabular}{|c|c|c|c|c|c|}
\hline \multirow{2}{*}{ Concrete } & \multirow{2}{*}{$\begin{array}{l}\text { Curing } \\
\text { Temp. } \\
{ }^{0} \mathrm{C}\end{array}$} & \multicolumn{4}{|c|}{ Age (days) } \\
\hline & & 3 & 7 & 14 & 28 \\
\hline \multirow{3}{*}{ PCC } & 25 & 15.41 & 22.44 & 26.07 & 33.93 \\
\hline & 30 & 18.89 & 23.11 & 26.82 & 30.89 \\
\hline & 50 & 20.00 & 23.48 & 25.33 & 27.64 \\
\hline \multirow{3}{*}{$10 \mathrm{FA}$} & 25 & 15.11 & 17.19 & 21.04 & 30.34 \\
\hline & 30 & 15.48 & 17.41 & 23.11 & 29.70 \\
\hline & 50 & 16.30 & 18.00 & 23.78 & 29.04 \\
\hline \multirow{3}{*}{$15 \mathrm{FA}$} & 25 & 14.05 & 16.15 & 18.82 & 28.00 \\
\hline & 30 & 15.11 & 16.30 & 20.07 & 27.19 \\
\hline & 50 & 15.47 & 17.93 & 21.04 & 26.15 \\
\hline
\end{tabular}

At early age i.e. three days; the strength of all concretes cured at $25^{\circ} \mathrm{C}$ (standard curing temperature) are quite similar, as shown in Fig. 1. The strengths of concrete at age 28-days at the curing temperature are 33.93, 30.34, and 28.0 MPa for concretes PCC, 10FA and 15 FA respectively. The results are unexpected, as the strength of fly ash concretes at the age 28-days, are significantly lower than that of PCC concrete i.e. $10.58 \%$ and $17.48 \%$ for $10 \mathrm{FA}$ and $15 \mathrm{FA}$ concretes respectively. It is believed as the PCC cement has been mixed with fly ash in clinker. Unfortunately, the percentage of fly ash, which had been added in clinker was not reported by the cement manufacturer.

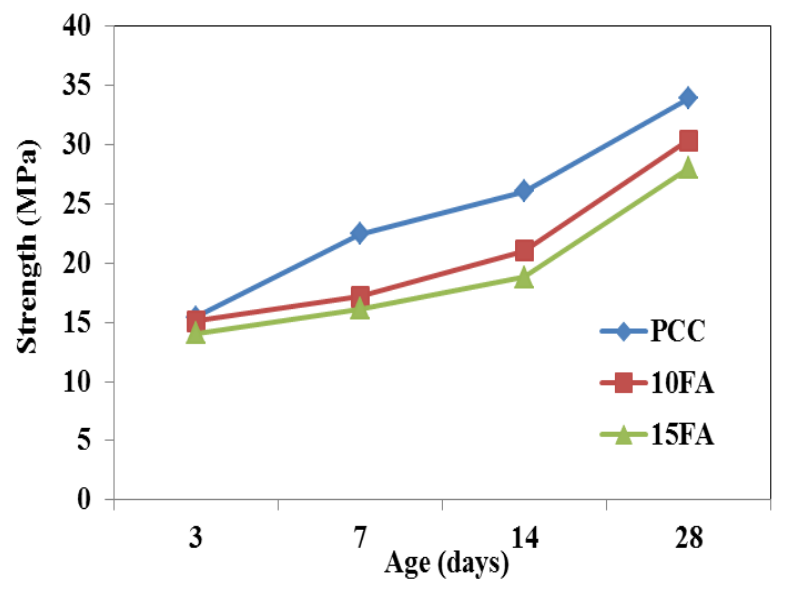

Fig. 1. Concrete strength vs. age cured at $25^{\circ} \mathrm{C}$. 
The strength development of all concretes at all testing ages are also presented in the Fig.1. At age 7 and 14 days, the strength of both 10FA and 15FA concretes are still much lower than that of PCC concrete. Even though, the strength of fly ash concretes at 28-days are still lower than that of PCC concrete. It is believed as the PCC cement have already contained much fly ash, which were mixed in cement clinker in cement manufacturing process. However, it seems that the strengths of $10 \mathrm{FA}$ and 15FA concretes are still developed to increase.

At elevated curing temperature $\left(30^{\circ} \mathrm{C}\right)$, the rate strengths of fly ash concrete up to age of 14-days are similar to that of fly ash concrete cured at standard curing temperature as shown in the following figure.

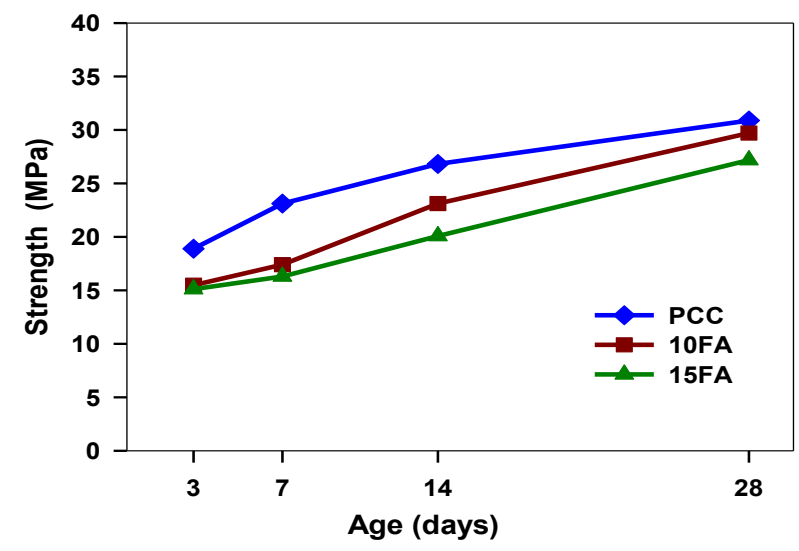

Fig. 2. Concrete strength vs. age cured at $30^{\circ} \mathrm{C}$.

However, at age 28-days, the strength of fly ash concretes significantly increase in comparing to the fly ash concretes cured at standard curing temperature as shown in Fig.2. The strengths of concrete at the age are 30.89, 29.70 and 27.19 MPa for PCC, 10FA and 15FA concretes respectively. The strengths of fly ash concrete reach $96.15 \%$ and $88.02 \%$ of the PCC concrete strength for 10FA and 15FA concretes respectively.

Furthermore, the strengths of fly ash concrete seem to sharply increase, while the strength development of PPC concrete is looked starting to be levelled. The detrimental effect due to a higher curing temperature at early ages to the strength development of concrete at later ages are still not appear as it generally happened on concrete cured at a similar temperature. It is believed as the fly ash can reduce the detrimental effect of the higher curing temperature at early ages to strength development of concrete at later ages.

Figure 3 displays the strength development of concretes against age for concretes cured at $50^{\circ} \mathrm{C}$.

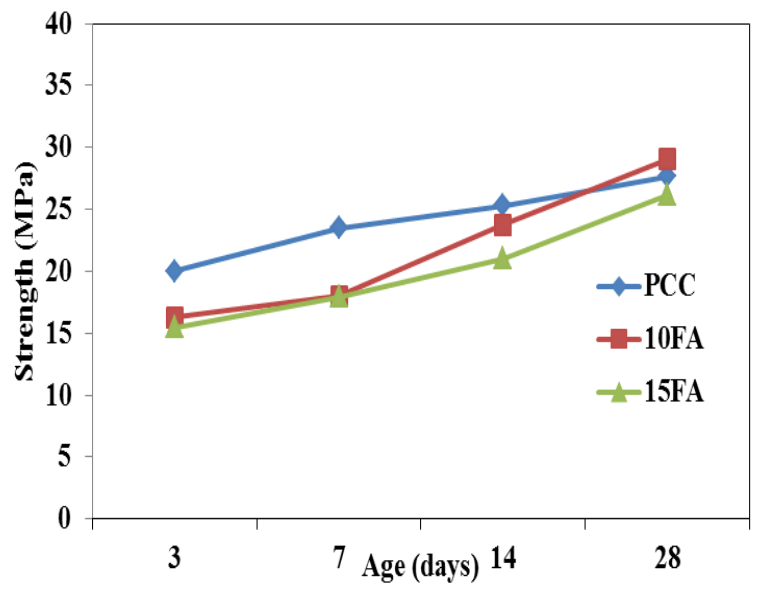

Fig. 3. Concrete strength vs. age cured at $50^{\circ} \mathrm{C}$.

The strength of PCC concrete at early age (3-days) is significantly higher $(29.79 \%)$ than that of PCC concrete cured at standard curing temperature. However, the strengths of both 10FA and 15FA concretes at the curing temperature are similar to those are cured at $25^{\circ} \mathrm{C}$. The strengths of both the concretes cured at $50^{\circ} \mathrm{C}$ are $18.50 \%$ and $22.65 \%$ lower than that of PCC concrete for 10FA and 15FA concretes respectively. The strengths of fly ash are continuously lower than that of PCC strength up to age of 14 days, where the strength of 10FA (23.78 $\mathrm{MPa})$ is closed to the PCC concrete strength (25.33 $\mathrm{MPa}$ ).

Furthermore, the strength of concrete with $10 \%$ fly ash at 28-days is slightly higher (5.07\%) than that of PCC concrete. Even the strengths of fly ash concretes seem to be still continuously developed rather than that of PCC concrete, which is seemed to start levelling.

Figure 4 presents the effect of higher curing temperature to the strength development of concrete at later ages (28-days). The figure shows that there is a detrimental effect of higher curing temperature at early to the later age's strength of concrete. The higher curing temperature results the higher detrimental effect to the strength of concrete.

At age 28-days, the strengths of PCC concrete decrease by $9.83 \%$ and $18.53 \%$ from its strength at standard curing temperature $\left(25^{\circ} \mathrm{C}\right)$ for curing at $30^{\circ} \mathrm{C}$ and $50^{\circ} \mathrm{C}$ respectively. 


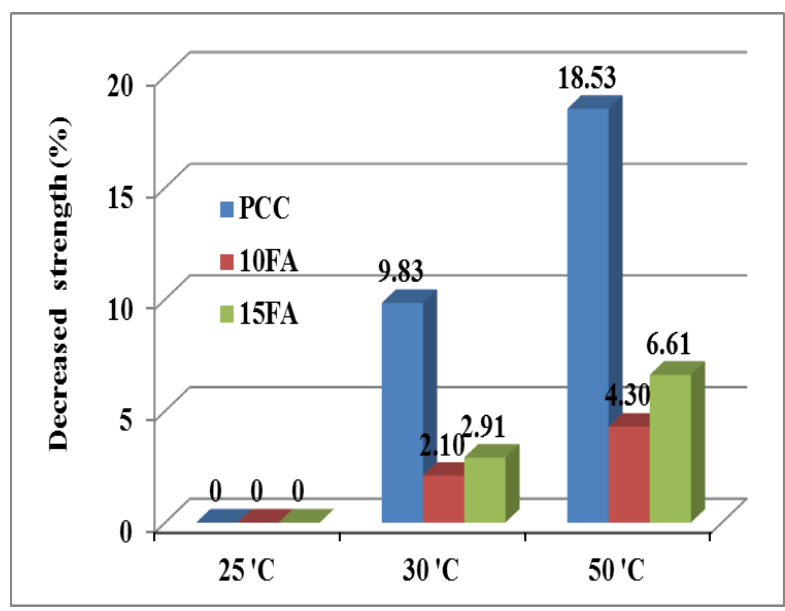

Fig.4. Effect of higher curing temperature to the strength concretes age 28-days

On the other hand, the detrimental effects on fly as concretes are significantly lower than that of happened in PCC concrete. For the 10FA concrete, the reducing strengths are $2.10 \%$ and $4.3 \%$ for 30 and $50^{\circ} \mathrm{C}$ respectively to the strength of 10FA concrete cured at standard temperature. Similarly, the reducing strengths of $15 \mathrm{FA}$ concrete are $2.91 \%$ and $6.61 \%$ for the curing temperature of 30 and $50^{\circ} \mathrm{C}$ respectively.

The high curing temperature at early age accelerates the hydration process of cement, as the result the hydration products of cement encase the remaining of cement, which has not hydrated yet. Therefore, the hydration process on the remaining cement cannot continue due to water cannot reach the part of cement. The hydration process of cement cannot occur without water.

The reaction of fly ash is an endotherm reaction, which needs some energy to start its reaction. The heat produced in cement hydration process i.e. primary reaction is absorbed by fly ash as the early energy to begin pozzolanic reaction. Therefore, the detrimental effect due to the high temperature can be overcome.

\section{Conclusions}

Based on the results of this research, the following conclusion can be drawn:

1. The effect of levels of fly ash in concrete cured at standard curing temperature has not significantly effect on the early age strength of fly ash concrete, when comparing their strength to the strength of PCC concrete. It is caused the PCC cement itself has already mixed with fly ash in clinker in the process of cement manufacturing.

2. At the elevated curing temperature $\left(50^{\circ} \mathrm{C}\right)$, the strength of Portland Cement Composite (PCC) only increases $(29.79 \%)$ at early age (three days), while the strengths of $10 \%$ (10FA) and $15 \%$ fly ash (15FA) concretes are still similar to their strength those cured at standard curing temperature.

3. The detrimental effect, which was caused by higher curing temperature at early ages on fly ash concretes, are less than that on PCC concrete, which are $18.53 \%, 4.3 \%$ and $6.61 \%$ for PCC, $10 \mathrm{FA}$ and $15 \mathrm{FA}$ concretes cured at $50^{\circ} \mathrm{C}$ respectively, while this problem has not been appeared on the concretes cured at $30^{\circ} \mathrm{C}$.

\section{References}

1. P.K. Mehta, High-performance, high-volume fly ash concrete for sustainable development. in Proceedings of the international workshop on sustainable development and concrete technology. Iowa State University Ames, IA, USA (2004).

2. S. Barbhuiya, and D. Kumala, Behaviour of a Sustainable Concrete in Acidic Environment. Sustainability, 9(1556): p. 13 (2017).

3. N. Makul., Concrete materials and manufacturing process for sustainable tomorrow: A review on current research and practical issues. (2017).

4. C. Meyer, Concrete and Sustainable Development. Special Publication ACI 206,Concrete Materials Science to Application - A Tribute to Surendra P. Shah American Concrete, Institute, Farmington Hills, MI p. 12 (2002).

5. A. Bilodeau and V.M. Malhotra, High-volume fly ash system: concrete solution for sustainable development. ACI Materials Journal, 97(1): p. 41-48 (2009).

6. T.R. Naik and B.W. Ramme, High early strength concrete containing large quantities of fly ash. ACI Mater. J, 86(2): p. 111-116 (1989).

7. M. Thomas, Optimizing the Use of Fly Ash in Concrete, in Concrete Thinking for a Sustainable World, Portland Cement Association. p. 24.

8. ACI-Committee-232.2R-03, Use of Fly Ash in Concrete, American Concrete Institute: Farmington Hills, MI (2004).

9. ASTM-Standard-C618-05, Annual Book of ASTM Standards, in Standard Specification for Coal Fly Ash and Raw or Calcined Natural Pozzolan for Use in Concrete, ASTM International: West Conshohocken, PA (2008).

10. G. Turuallo and H. Mallisa. Sustainable Development: Early Age Strength of HSC Using Fly Ash to Replace Part of Cement, in Sriwijaya International Conference on Engineering, Science and Technology (SICEST). Faculty of Engineering, Sriwijaya University. Bangka Island, Indonesia (2016).

11. G. Turuallo and H. Mallisa. Using Cementitious Materials Such as Fly Ash to Replace a Part of Cement in Producing High Strength Concrete in Hot Weather, in IOP Conference Series: Materials Science and Engineering. IOP Publishing (2018).

12. A. Bilodeau, et al., Durability of concrete incorporating high volumes of fly ash from sources in the USA. Materials Journal, 91(1): p. 3-12 (1994). 
13. G. Turuallo, Using ggbs for Partial Cement Replacement in Concrete: Effects of Water-binder Ratio and ggbs Level on Activation Energy. International Journal of Technology, 6(5): p. 790799 (2015).

14. G. Turuallo, Early age strength development of ggbs concrete cured under different temperatures. $\mathrm{PhD}$ Thesis, Liverpool University: Liverpool, UK, (2013)

15. S.K. Bremseth, Fly ash in concrete: A literature study of the advantages and disadvantages, SINTEF Building and Infrastructure: Forskningsveien 3 B PO Box 124 Blindern (2009). 